безпритульні діти, діти-сироти). у психолого-педагогічному контексті соціалізація дітей з особливими освітніми потребами складає інтегровану частину інклюзивного підходу до навчання й виховання у шкільному середовищі. Установлено, що наприкінці $X X$ - початку XXI cm. в Україні трактування наукової дефрініції «особа з особливими освітніми потребами» було суттєво звужене, $i$, зазвичай, використовувалося під час упровадження інклюзії для дітей із порушеннями психофізичного розвитку. Соціалізація дітей із особливими освітніми потребами передбачає поступове входження дитини в освітнє середовище, під час якого відбувається засвоєння й відтворення соціальних норм, цінностей, культури, знань та навичок через комунікативну взаємодію з учасниками освітнього прочесу та участь у практичній діяльності.

Ключові слова: потреби, особливі потреби, особливі освітні потреби, діти з особливими освітніми потребами, інклюзія, інклюзивний підхід, соціалізація, семантичний аналіз.

Удк 371.3

Світлана Хоменко

Дніпровський національний університет імені Олеся Гончара

ORCID ID 0000-0002-1443-8308

DOI 10.24139/2312-5993/2020.09/085-097

\title{
ЕТАПНІСТЬ РОЗВИТКУ СИСТЕМИ РАННЬОÏ ДОПОМОГИ В УКРАЇНІ
}

у статті досліджено й визначено етапи розвитку системи ранньої допомоги в Україні на основі узагальнення законодавчого підгрунтя за роки незалежності України щодо розвитку системи освіти дітей із особливими потребами й міжнародної та вітчизняної практики ранньої допомоги дітям з народження. Проаналізовано основні положення, задекларовані в міжнародних і національних законодавчих нормативноправових документах організації системи ранньої допомоги дітям із особливими освітніми потребами в різні часові періоди, описано існуючу практику організації ранньої допомоги на кожному етапі ії становлення в Україні.

Ключові слова: діти раннього віку, рання реабілітація, державна політика, рання допомога, раннє втручання, діти з особливими освітніми потребами.

Постановка проблеми. Різні галузі сучасного наукового знання характеризуються інтересом до ранніх етапів розвитку людини. У спеціальній педагогіці й психології проблеми ранньої допомоги дітям із особливими освітніми потребами займають провідне місце (Л. Аксьонова, О. Мастюкова, Ю. Разєнкова, О. Стребєлєва, В. Тарасун, М. Шеремет та ін.). 3 перших днів життя дитини відбувається становлення важливих рис особистості, задається напрям формування ії життєвого маршруту. Діти до 18 років «з особливими освітніми потребами», за законодавчо (у 2010 р.) схваленим терміном, підростаючи, спричинюють надзвичайну проблему в галузі охорони здоров'я і освіти, бо потребують додаткової навчальної, медичної й соціальної підтримки з метою покращення здоров'я, розвитку, навчання, загальної якості життя та соціалізації, тобто ранньої комплексної допомоги з народження (сайт МОН України). 
Це зумовило реорганізацію й оновлення системи спеціальної освіти, на основі принципів демократизації й гуманізації, визнання права кожної дитини на одержання освіти, адекватної її пізнавальним можливостям і вимогам часу. Реалізація цього завдання можлива, за висновками зарубіжних вчених (С. Барет, М. Гуральнік, Т. Мур, Н. Доброва-Крол та ін.) і міжнародного досвіду, організації системи ранньої допомоги дітям із раннього віку (Доброва-Крол, 2014).

Аналіз останніх досліджень. У теорії і практиці спеціальної педагогіки доведена значущість раннього виявлення й корекції порушень розвитку дітей з народження зарубіжними (В.Брутман, Г. Філіппова, Е. Ляксо, М. Гуслова, Т. Стурета та ін.) і вітчизняними (О. Архіпова, Л. Виготський, Ю. Разенкова, О. Стрєбєлєва, В. Ремажевська, Т. Панченко, А. Заплатинська та ін.) вченими. Тому практичне надання ранньої допомоги дітям із особливими освітніми потребами в Україні стало найважливішим пріоритетом розвитку сучасної системи спеціальної освіти. Така позиція базується на культурно-історичній теорії Л. Виготського і його наукової школи, представники якої (Л. Божович, О. Запорожець, О. Леонтьєв, Д. Ельконіна та ін.) довели унікальність перших років життя дитини для ії розвитку. Ранню допомогу розглядають (С. Миронова, В. Рагозіна, Г. Кукуруза, М. Кропівницька та ін.) як новий напрям у вітчизняній спеціальній освіті, який розвивається на основі мультидисциплінарного підходу, реалізуючи ідеї гуманістичної й особистісноорієнтованої освіти. Саме організація ранньої допомоги від народження до 3x років, коли відбувається стрімке та інтенсивне первинне формування якостей і властивостей особистості (Л. Виготський, Л. Венгер, О. Запорожець, Д. Ельконін та ін.), дозволяє створювати умови для ефективного психофізичного розвитку й особистісного розвитку, забезпечує в подальшому рівні права на отримання освіти всіх дітей, у тому числі дітей із особливими освітніми потребами та інших соціально вразливих груп.

Мета статті - визначити етапи становлення системи ранньої допомоги в Україні на основі аналізу й узагальнення законодавчого підгрунтя міжнародної та вітчизняної практики.

Для досягнення мети дослідження були визначені завдання - на основі аналізу спеціальної вітчизняної і зарубіжної літератури, законодавчих документів визначити й коротко схарактеризувати етапи становлення системи ранньої допомоги в галузі освіти та потенційні ресурси подальшого розвитку.

Методи та методики дослідження. У написанні статті було використано такі методи: аналіз, синтез та узагальнення нормативно-правових 
документів, різних текстових тематичних матеріалів, наведених у бібліографії з проблем ранньої допомоги дітям із особливими освітніми потребами.

Виклад основного матеріалу. Право на освіту всіх людей, які могли би стати корисними членами суспільства при одержанні належної освіти було проголошено на 23-й Женевській міжнародній конференції 3 народної освіти (1960). Це право було закріплено «Конвенцією про боротьбу з дискримінацією в галузі освіти» (1960), «Міжнародною конвенцією про ліквідацію всіх форм расової дискримінації», що в подальшому послужило впровадженню концепцій «Відкритого громадського суспільства» i «безперешкодного доступу до освіти» та спричинило розвинені країни Європи (США, Німеччина, Англія, Франція, Швеція, Данія, Нідерланди, Фінляндія та ін.) обґрунтувати необхідність створення умов для розвитку й виховання для дітей із народження. Раннє втручання як система надання ранньої допомоги дітям із особливими освітніми потребами за дослідженням О. Ємєліної (2013р.) розвивається в Європі та США з 50-60-х років і охоплює періоди: перший - з 60-х до 80-х років XX-го ст., що характеризується новими ідеями цінного впливу соціума і сім'ї на розвиток дитини з народження; другий - з 1990-х рр. і донині характеризується пріоритетом цілістного соціально-педагогічного підходу до особистості дитини (Krauss \& Jacobs, 1990) й задоволення особливих потреб в освіті та соціалізації дітей раннього віку (Ємєліна, 2013).

Порівняно з Європою і США в 60-х рр. Україна була у складі СРСР, де існувала державна система громадського виховання дітей раннього віку в закладах - ясла, ясла-садок, що мають певну історію розвитку. Система виховання дітей раннього віку будувалася на основі наукових досліджень Інституту педіатрії АМН СРСР, Центрального інституту удосконалення лікарів (1950), кафедри фізіології розвитку і виховання дітей, керованою М. Щеловановим та Н. Аксаріною (1967) та ін. Раннє виявлення та корекція відхилень у розвитку $\epsilon$ основоположним принципом української спеціальної педагогіки, що визначалося провідною роллю виховання й навчання в розвиткові дітей у дослідженнях Л. Виготського. На думку європейських учених (Дж. Джонсона, В. Міллера та В. Мілса), культурноісторична теорія розвитку вищих психічних функцій Л. Виготського співзвучна з ідеями соціального включення, що $€$ теоретичною основою програм ранньої допомоги та слугували підґрунтям для розвитку теорії інтеграції. Ці теорії й організаційні форми соціально-педагогічної діяльності набули значного поширення і законодавчої підтримки в країнах Заходу (Peters, 2003; Lipsky, 1996; Вигоцький, 2003). 
У сфері охорони здоров'я робота, що спрямовувалася на корекцію здоров'я та порушень дітей від народження до 3-х років, була доступною й більш розгалуженою (пологові будинки, поліклініки, стаціонари лікарень, санаторії, дитячі будинки) порівняно з системою освіти, бо за домінувальною медичною моделлю дитину вважали хворою, яка потребує певного лікування.

У 70-ті роки становлення теорії і практики допомоги дітям раннього віку здійснювалися фахівцями медичної й педагогічної галузей (Н. Аксаріна, М. Кістяковська, М. Кольцова, Н. Ладигіна, М. Лісіна, Г. Ляміна, Н. Фігурін, Ф. Фрадкіна, М. Щелованов та ін.), а розроблені зміст, форми і методи й нині $\epsilon$ теоретико-методичною основою для роботи 3 дітьми раннього віку. 3 кінця 80-х років в Україні Міністерством охорони здоров'я вперше розроблено єдину систему раннього виявлення дітей із порушеним слухом, яку впроваджено в країні як обов'язкову (Е. Леонгард, Т. Пелимська, Н. Шматко).

Отже, до 90-х років політика радянської держави була орієнтова на допомогу дітям раннього віку, переважно, за медичною моделлю. Проте, накопичений теоретичний і практичний досвід розвитку дітей раннього віку став базовим у становленні ранньої допомоги в сучасних умовах.

3 прийняттям Верховною Радою УРСР Декларації про державний суверенітет України (від 16 липня 1990 р.) та Акту проголошення незалежності України (від 24 серпня 1991 р.) у розвитку системи спеціальної освіти окреслюються кілька етапів, часові межі яких визначаються суспільнополітичними та соціокультурними процесами. у перший рік своєї самостійності було ратифіковано міжнародний документ «Конвенцію про права дитини» (1991р.), на базі якої почали розробляти власну законодавчу базу, у першу чергу - національного освітнього законодавства. Конвенція стала частиною національного законодавства та сприяла започаткуванню першого етапу розвитку ранньої допомоги в системі спеціальної освіти (1990-2000 рр.). Розпочалося впровадження нової стратегії розвитку освіти на концептуальних засадах «суспільство для всіх», «освіта для всіх».

Для утвердження розуміння того, що спеціальна освіта повинна орієнтуватися на формування гармонійно розвиненої особистості на основі реалізації соціальної моделі допомоги був створений Інститут спеціальної педагогіки (1993р.). Колективом Інституту спеціальної педагогіки були розроблені Концепція спеціальної освіти дітей $з$ особливостями психофізичного розвитку на найближчі роки і перспективу (1996), Концепція реабілітації дітей з обмеженими фізичними чи розумовими 
можливостями (1998), Концепція державного стандарту спеціальної освіти (1999) та ін. Розвитку системи спеціальної освіти й системи ранньої допомоги дітям раннього віку в тому числі, були присвячені дослідження
В. Бондаря,
Л. Борщевської,
Л. Вавіної,
О. Гаврилова,
В. Засенка,

А. Колупаєвої, С. Миронової, В. Липи, В. Синьова, М. Супруна, В. Тарасун, Л. Федорович, А. Шевцова, М. Шеремет та ін. Реалії розвитку спеціальної освіти поставили перед педагогічною наукою і практикою завдання (В. Бондарь, В.Синьов та ін.) пошуку оптимальних умов навчання й виховання дітей раннього віку з різними освітніми потребами.

Був започаткований спільний українсько-німецький проєкт у галузі охорони здоров'я - Український медичний центр реабілітації дітей з органічним ураженням нервової системи МОз України (1996р.), схвалено Концепцію вдосконалення неврологічної допомоги дітям України (1998р.), запроваджено модель медико-соціальної реабілітації дітей з органічним ураженням нервової системи «Тандем-партнерство», «Дитина-сім'я-фахівець», в основі діяльності якої гармонійно поєднано медичні та психолого-педагогічні аспекти реабілітації (мультидисциплінарна команда) (Мартинюк, 2011).

Паралельно при Міністерстві соціального захисту України була організаційно створена система дитячих центрів соціальної реабілітації дітей-інвалідів, які за своєю сутністю функціонують у фаховому полі центрів соціальної педіатрії.

За сприяння волонтерів 3 Канади й ініціативи батьків дітей 3 церебральним паралічем товариства «Надія» була заснувана в 1993 році благодійна установа Навчально-реабілітаційний центр «Джерело» як перший прояв початку організації раннього втручання (сайт навчальнореабілітаційного центру «Джерело»).

3 ініціативи Фонду соціального захисту інвалідів та за підтримки Міністерства праці та соціальної політики України був відкритий Центр ранньої соціальної реабілітації дітей-інвалідів у Миколаєві (Миколаївська модель раннього втручання, 1996 р.). Протягом двох років співробітництва з американською стороною (Інститутом Елвіна) українські фахівці освоїли методику «Раннього втручання».

Запровадження програми раннього втручання почалося в М. Харкові (1998р.) в межах дослідницького проекту, основною метою якого було вивчення світового досвіду раннього втручання та створення моделі, яка базувалася на міжнародному досвіді та враховувала українські реалії.

Отже, зміна державного устрою й розбудова незалежної України зумовили ратифікацію міжнародних документів стосовно дітей із особливими 
освітніми потребами, що сприяли організації окремих практик ранньої допомоги як першого етапу (1990-2000рр.) започаткування ранньої допомоги.

Другий (2001-2010 рр.) етап розвитку ранньої допомоги ознаменувався новим методологічним і соціально-економічним контекстом, зумовлених процесами європейської інтеграції та світової глобалізації й ініціативами батьківської спільноти, громадськими організаціями, які базувалися на переконанні, що всі діти можуть навчатися, здобувати якісну освіту, реалізувати свій потенціал та інтегруватися в суспільство.

Після прийняття Постанови «Про схвалення Концепції ранньої соціальної реабілітації дітей-інвалідів» (2000р.), законів «Про дошкільну освіту» (2001р.) й «Про охорону дитинства» (2001р.), рання допомога дітям була активізована, почали створюватися центри раннього втручання, як система міждисциплінарної сімейно-центрованої допомоги. Першим було створено Центр раннього втручання під керівництвом Г. Кукурузи (м. Харків, 2000), де отримували міждисциплінарну допомогу сім'ї з дітьми із особливими освітніми потребами, викликані медичними, біологічними і соціальними чинниками (Кукуруза, 2013).

У 2003 році, за сприяння посольства США в межах реалізації проєкту «Правовий захист дітей-інвалідів» (м. Рівне) була створена обласна асоціація батьків дітей із особливими потребами. Асоціація батьків у партнерстві з ОМНІ-Мережею, за підтримки місцевої влади ініціювала під егідою управління освіти створення Центру ранньої педагогічної реабілітації і соціальної адаптації дітей з особливими освітніми потребами «Пагінець» - першого державного закладу в Україні (Бастун, 2005).

На виконання законів «Про державні соціальні стандарти та державні соціальні гарантії» (2000р.) й «Про соціальні послуги» (2003р) був розроблений проєкт Державного стандарту якості послуг раннього втручання (у 2006 р.) для дітей віком від 0 до 6 років з порушеннями розвитку та їх сімей. Розробники - «Інститут раннього втручання» (Росія), Український фонд соціальних інвестицій і робоча група в складі фахівців з різних міст України, що працюють у сфері допомоги маленьким дітям. Після, практично, повного знищення ясельної системи виховання розпочалося реформування дошкільної освіти дітей з особливими потребами (2008р.). Набула поширення нова модель ранньої допомоги дитині з особливими потребами із залученням батьків у корекційно-розвивальний процес у створюваних «Центрах розвитку дитини» (Кукуруза, 2013).

у м. Луцьку за зверненням батьків до органів державної влади ініційовано створення обласного Центру раннього втручання (2006р.) в 
структурі існуючого Будинку дитини. У м. Хмельницькому спільно з Українським фондом соціальних інвестицій (УФСІ), Шведським Агентством з міжнародного розвитку (SIDA), органами місцевої (міської) влади та ОМНІ-Мережею розпочато створення Інформаційно-консультативного центру для родин, що мають дітей із особливими потребами. До роботи в центрі залучена мультидисциплінарна команда спеціалістів (педіатр, лікаргенетик, психолог, логопед, соціальний працівник (Бастун, 2005).

На базі міського центру реабілітації «Джерело» запрацювала Львівська модель раннього втручання (2008р.) як комплексна система послуг сім'ї, у якій народилася дитина з неповносправністю чи ризиком розвитку такої. Система послуг для дітей віком від 0 до 4 років скерована на раннє виявлення, терапію та профілактику порушень розвитку дитини та функціонування ії сім'ї й забезпечується мультидисципліонарною командою фахівців (Ремажевська, 2007).

У системі охорони здоров'я реалізувався Національний проєкт «Нове життя - нова якість охорони материнства і дитинства», відповідно до Указу Президента України від 8 вересня 2010 року, що сприятеме подоланню негативних демографічних тенденцій. Це відкриття регіональної мережі перинатальних центрів і реорганізація системи надання медичної допомоги вагітним і новонародженим, забезпечення нормальної якості медичних послуг для новонароджених, зниження дитячої та материнської смертності. У таких центрах виходжують недоношених немовлят та надають їм вузькоспеціалізовану допомогу з використанням найсучасніших медичних технологій.

Отже, зміна державної політики у сфері освіти стимулювала локальне створення мережі перинатальних, навчально-реабілітаційних центрів державного і комунального підпорядкування й організації ранньої допомоги дітям завдяки поширення руху батьків та підтримці міжнародних організацій і запозичення досвіду причетних до розвитку системи раннього втручання.

Прийняття «Концепції розвитку інклюзивної освіти» (2010р.) й уведення до законодавчого поля визначення інклюзивного навчання як комплексного процесу забезпечення рівного доступу до якісної освіти дітей з особливими освітніми потребами шляхом організації їх навчання в закладах загальної середньої освіти. Уперше було введено термін спеціальні та інклюзивні класи для навчання дітей з особливими освітніми потребами (Федоренко, 2013). Це потребувало створення системи раннього виявлення й ранньої комплексної допомоги дітям із особливими освітніми потребами, тобто добудову нового структурного елементу в системі спеціальної освіти (Колупаєва, 2009). 
Саме необхідність розвитку ранньої допомоги як системи й добудова структурного елементу, що забезпечить поступовий перехід до інклюзивної освіти та збільшення числа «шкіл для усіх» спричинили третій (з 2011 р. донині) етап розвитку системи ранньої допомоги в Україні й реалізацію права на освіту і охорону здоров'я дітей із особливими освітніми потребами 3 урахуванням індивідуальних особливостей навчально-пізнавальної діяльності. Розроблена «Концепція становлення і розвитку особистості дитини переддошкільного віку з обмеженими можливостями здоров'я» В. Тарасун (2011) мала особливу значущість для педагогічної практики, основні напрями якої визначалися державною політикою у сфері дошкільної освіти: Концепцією розвитку дошкільної освіти, законом України «Про дошкільну освіту» (2001р.), наказом «Про додаткові заходи щодо підвищення якості освіти в Україні» (2008р.), відповідно до яких дошкільна освіта $\epsilon$ обов'язковою первинною ланкою системи освіти.

Сучасна спеціальна освіта в Україні являє собою складну, розгалужену й диференційовану систему, що має вертикально-горизонтальну структуру. Вертикальна структура базується на вікових особливостях учнів і рівнях загальноосвітніх програм. Вертикальна структура визначається віковими періодами: раннього дитинства (від 0 до 3 років); дошкільного періоду (з 3 до 6-7 років); періоду шкільного та професійного навчання (з 6-7 до 16-21 років). Горизонтальна структура враховує психофізичний розвиток дитини, особливості її пізнавальної діяльності та характер порушення. Основними державними закладами освіти для дітей 3 особливими потребами дошкільного та шкільного віку $є$ : спеціальні дошкільні та загальноосвітні школи-інтернати, навчально-реабілітаційні центри, навчально-виховні комплекси та інклюзивні групи і класи в закладах загальної середньої освіти масового типу тощо (Колупаєва, 2014).

Завдання розвитку системи раннього втручання в Україні були зафіксовані в Рекомендаціях парламентських слухань на тему: «Освіта, охорона здоров'я та соціальне забезпечення дітей 3 порушеннями психофізичного розвитку: проблеми та шляхи їх вирішення» (2015р.). Основою для цього вважалося наявне наукове, практичне й методичне підґрунтя, що зафіксоване в постанові «Про створення в Україні системи раннього втручання для реабілітації дітей перших років життя (2012р.) Президією Національної академії медичних наук України. На виконання Загальнодержавної програми «Національний план дій щодо реалізації Конвенції ООН про права дитини» (2015р.) на період до 2016 року доручено пілотне впровадження в медичну практику надання послуг раннього 
втручання й надання підтримки родинам, які виховують дітей із порушеннями розвитку. У 2016 році підписано меморандум між Міністерством охорони здоров'я України, Міністерством освіти і науки України, Міністерством соціальної України, Європейською асоціацією раннього втручання, а також ВГО «Національна Асамблея людей 3 інвалідністю», БФ «Інститут раннього втручання», фундацією SOFT Tulip (Нідерланди) та іншими щодо запровадження національної платформи раннього втручання. У Меморандумі передбачено об'єднання зусиль усіх інституцій, які підписали документ, та створення єдиної національної платформи раннього втручання, яка координуватиме роботу різних органів влади, міжнародних і національних організацій у функціонуванні системи раннього втручання в Україні. Для практичного впровадження Кабінет Міністрів України видав Розпорядження «Деякі питання реалізації пілотного проєкту «Створення системи надання послуг раннього втручання» для забезпечення розвитку дитини, збереження ії здоров’я та життя» (2016 р.) та затвердив план заходів. Практика надання послуг раннього втручання дітям із порушенням здоров'я та розвитку і ризиком їх виникнення та сім'ям, що їх виховують, упроваджується на рівні адміністративно-територіальних одиниць Закарпатської, Львівської, Одеської та Харківської областей (Панченко та Заплатинська, 2018).

Нині вже започатковано надання таких послуг у комунальних закладах охорони здоров'я, освіти, соціального захисту населення та недержавних організаціях. Згідно розпорядження Кабінету Міністрів України «Про визначення національного координатора» (2019 р.), національним координатором із питань упровадження послуги раннього втручання в межах пілотного проєкту визначено Міністерство соціальної політики України. Разом із тим, з 2016 року в межах проєкту UNICEF «Підготовка команд раннього втручання і фахівців у громаді» здійснюється навчання фахівців технології надання цієї послуги. Навчання команд проводиться Благодійним Фондом «Інститут раннього втручання» міста Харкова за підтримки таких організацій: УРЦ «Джерело» (м. Львів), ДУ «Інститут охорони здоров'я дітей та підлітків НАМН України», Харківський обласний спеціалізований будинок дитини №1 (сайт Верховної Ради України).

Останньою інституційною трансформацією в Україні щодо розвитку системи ранньої допомоги стало реформування з 1 вересня 2017 року психолого-медико-педагогічних консультацій на Інклюзивно-ресурсні центри, які повноцінно запрацювали з 1 вересня 2018 року на основі постанов Кабінету Міністрів України: «Про затвердження Положення про інклюзивно- 
ресурсний центр» (2017р.), «Про деякі питання використання субвенції 3 державного бюджету місцевим бюджетам на надання державної підтримки особам з особливими освітніми потребами у 2018 р.» тощо. Нині система раннього втручання вирішує такі завдання: раннє виявлення дітей 3 проблемами розвитку; забезпечення міждисциплінарної комплексної оцінки стану здоров'я і розвитку дитини, психолого-педагогічних здібностей і можливостей батьків та інших членів сім'ї; визначення потреб дитини і сім'ї на основі виявлених діагностичних показників та розробка індивідуальної програми їх корекції; організація процесу надання ранньої допомоги дитині й підтримки членам сім'ї; забезпечення наступності між установами охорони здоров'я і освіти та сім'єю.

Отже, на третьому (з 2011 р. - донині) етапі розвитку системи ранньої допомоги розроблені й затверджені нормативно-правові документи, науково-теоретична база щодо створення системи раннього втручання в Україні.

\section{Висновки та перспективи подальших наукових розвідок.} Досліджуваний процес становлення української системи ранньої допомоги дітям із особливими освітніми потребами відбувався впродовж трьох етапів: перший (1990-2000рр.) етап розвитку ранньої допомоги розпочався з набутям державної самостійності й рзробкою власних та ратифікацією міжнародних документів; другий (2001-2010рр.) етап розвитку ранньої допомоги характеризується активізацією нових методологічних засад і запозиченням міжнародного досвіду раннього втручання та впровадження локальної практики ранньої допомоги в системі охорони здоров'я, освіти та соціаьного забезпечення; третій (з 2011 року - донині) етап розвитку системи ранньої допомоги розпочався із введення до законодавчого поля «Концепції розвитку інклюзивної освіти» (2010р.) й визначення інклюзивного навчання як комплексного процесу, що включає систему ранньої допомоги дітям із особливими освітніми потребами як базову.

Перспективи подальшого вивчення системи ранньої допомоги вбачаємо в розробці комплексних програм і методик для роботи в єдиній державній системі раннього виявлення та спеціальної допомоги дітям раннього віку з особливими освітніми потребами та їхнім сім'ям.

\section{ЛІТЕРАТУРА}

Бастун, Н. А. (2005). Служби раннього втручання в Україні: шлях до інтеграції. К., ІКЦ «Леста» (Bastun, N. А. (2005). Early intervention services in Ukraine: the path to integration. $K_{.}, I C C$ «Lesta»).

Выготский, Л. С. (2003). Принципы воспитания физически дефективных детей. Основы дефректологии. С-П, М. Изд-во «Лань» (Vygotsky, L. S. (2003). Principles of raising 
physically defective children. Fundamentals of defectology. SP, M. Publishing House «Lan»).

Доброва-Крол, Н. (2014) Раннее вмешательство: ключевые аспекты и международный опыт. Международный детский фонд ООН (ЮНИСЕФ). Киев (Dobrova-Krol, N. (2014). Early Intervention: Key Aspects and International Experience. UN International Children's Fund (UNICEF). Kyiv).

Емелина, О. И. (2013). Становление системы помощи детям раннего возраста за рубежом. Специальное образование, 3, $49-55$ (Emelina, O. I. (2013). Establishment of a system of assistance to young children abroad. Special education, 3, 49-55).

Інклюзивне навчання. Міністерство освіти і науки України. Режим доступу: https://mon.gov.ua/ua/tag/inklyuzivne-navchannya (Inclusive education. M inistry of Education and Science of Ukraine). Retrieved from: https://mon.gov.ua/ua/tag/inklyuzivne-navchannya

Колупаєва, А. А. (2014). Спеціальна освіта в Україні та модернізація освітньої галузі. Особлива дитина: навчання і виховання, 3, 7-11 (Kolupaieva, A. A. (2014). Special education in Ukraine and modernization of the educational branch. Special child: education and upbringing, 3, 7-11).

Колупаєва, А. А. (2009). Інклюзивна освіта: реалії та перспективи. К.: «Самміт-Книга» (Kolupaieva, A. A. (2009). Inclusive education: realities and prospects: Monograph. K.: «Summit Book»).

Кропівницька, М. Е. (2019). Впровадження послуги раннього втручання на рівні пілотних областей в Україні. Інвестиції: практика та досвід, 6, 132-137. Режим доступу: http://www.investplan.com.ua/ $0 p=1 \& z=6596 \& i=23$ (Kropivnytska, M. (2019). Early intervention service implementation at the level of the pilot areas in Ukraine. Investment: practice and experience, 6, 132-137. Retrieved from: http://www. investplan.com.ua/?op=1\&z=6596\&i=23).

Кукуруза, А. В. (2013). Раннее вмешательство - семейно-центрированная модель помощи семьям, воспитывающим детей раннего возраста с нарушениями развития. Психология, 9, 99-102 (Kukuruza, А. V. (2013). Early intervention is a family-centered model of care for families raising young children with developmental disabilities. Psychology, 9, 99-102).

Мартинюк, В. Ю. (2011). Соціальна педіатрія в Україні: концепція, завдання, перспективи. Медична газета «здоров'я України». Педіатрія, 1, 1-4 (M artyniuk, V. Yu. (2011). Social pediatrics in Ukraine: concept, tasks, prospects. Medical newspaper «Health of Ukraine». Pediatrics, 1, 1-4).

Назарова, Н. М., Моргачева, Е. Н., Фуряева, Т. В. (2011). Сравнительная специальная педагогика. М.: Издательский центр «Академия» (Nazarova, N. M., M orgacheva, E. N., Furiaieva, T. V. (2011). Comparative special pedagogy. M., Publishing Center «Academy»).

Панченко, Т. Л., Заплатинська, А. Б. (2018). Раннє втручання як система комплексної допомоги дітям раннього та дошкільного віку. Народна освіта, 3 (36). Режим доступу: https://www. narodnaosvita. kiev. ua/? page_id 5463 (Panchenko, T. L., Zaplatinskaya, A. B. (2018). Early intervention as a system of comprehensive care for children of early and preschool age. Public education, 3 (36). Retrieved from: https://www. narodnaosvita. kiev. ua/? page_id 5463).

Ремажевська, В. М. (2007). Науково-організаційні основи створення системи ранньої комплексної допомоги дітям з вадами зору. Актуальні проблеми навчання та виховання людей з особливими потребами. Збірник наукових праць, 4 (6). Режим доступу: http://ap.uu.edu.ua/article/289 (Remazhevska, V. M. (2007). 
Scientific and organizational bases of creating a system of early comprehensive care for children with visual impairments. Current problems of education and upbringing of people with special needs. Collection of scientific works, 4 (6)).

Сайт навчально-реабілітаційного центру «Джерело». Режим доступу: http://www.dzherelocentre.org.ua/ (The site of the training and rehabilitation center «Source». Retrieved from: http://www.dzherelocentre.org.ua/).

Шевченко, В. (2019). Підготовка фахівців до роботи з дітьми з особливими потребами в сучасних умовах. Педагогічні науки: теорія, історія, інновачійні технології, 4 (88), 340-350 (Shevchenko, V. (2019). Training of specialists for work with children with special needs in modern conditions, 4 (88), 340-350).

Lipsky, D. \& Gartner, A. (1996). School Reform and Inclusive Education. Baltimore: Paul H/Brooks.

Peters, G. (2003). Inclusive Education: Achieving Education for All by Including Those with Disabilities and Special Education Needs. World Bank, April 30.

\section{PEЗЮME}

Хоменко Светлана. Этапность развития системы ранней помощи в Украине.

В статье исследованы и определены этапы развития системы ранней помощи в Украине на основе обобщения законодательной основы за годы независимости Украины по развитию системы образования детей с особыми потребностями и международной, отечественной практики ранней помощи детям с рождения. Проанализированы основные положения, задекларированные в международных и национальных законодательных нормативно-правовых документах организации системы ранней помощи детям с особыми образовательными потребностями в разные временные периоды, описано существующую практику организации ранней помощи на каждом этапе ее становления в Украине.

Ключевые слова: дети раннего возраста, ранняя реабилитация, государственная политика, ранняя помощь, раннее вмешательство, дети с особыми образовательными потребностями.

\section{SUMM ARY}

Khomenko Svitlana. The developmental stages of the early assistance system in Ukraine.

The article examines the development of the early assistance system for young children, as an integral part of the implementation of the Ukrainian state policy in the field of education that ensures children's rights defined by the international and national legislation, and the stages of its formation. Early assistance is viewed as an interdisciplinary familycentred system of comprehensive care for young children with developmental disabilities and children form biological and social risk groups, aimed at children's better development and better quality of life in their families. We have reviewed, synthesized and generalized regulatory documents, methodological manuals and other reference thematic materials given in the bibliography, analyzed the main provisions declared in international and national legislative documents for organization of the early assistance system for children with special educational needs in different time periods, described the existing practices of early assistance at each stage of its development.

The author has found out that formation of the Ukrainian system of early assistance for children with special educational needs took place in three stages: the first (1990-2000) stage began with the acquired state independence and ratification of international documents; the second (2001-2010) stage included development of new methodological foundations basing on the international experience of early intervention and introduction of early assistance into local practices applied in health care, education and social security; the 
third (from 2011 - to the present) stage began with introduction of the Concept for the Development of Inclusive Education (2010) into the national legislative field and the definition of inclusive education as an integrated process, including the early assistance system for children with special educational needs.

Key words young children, early rehabilitation, public policy, early care, early intervention, children with special educational needs. 